\title{
Absentia Voter in The Election of Regional Head in Situbondo Regency Year 2015
}

\author{
Rupiarsieh \\ Faculty of Social and Political Science \\ Universitas Bojonegoro \\ Bojonegoro, Indonesia \\ arsieh_sakti@yahoo.com
}

\begin{abstract}
Since the downfall of the New Order regime, the regional head election is done directly. Before 2005, it was ellected by the Local House of Representatives (Dewan Perwakilan Rakyat Daerah, DPRD). However, since the effectuation of Constitution No. 32 year 2004 said that the regional head were chosen directly by the people and called as Pilkada. It was held in 2010 and 2015. In the 2015 elections in Situbondo, the number of absentia voter is still a problem. It shows that the public has little or no political participation in using their right to vote freely. It is very influential on democracy and acceptance of the elected leaders.

The voters are not in accordance with the existing leader candidate, do not attend the election. The voters will attend the election by following the advice from the Kiayi. They chose their regency leader not in freely condition. If the elected regent unable to accommodate the interests of the opposing party (absentia voter) could become a powerful political opponent. A new factor affecting the absentee voter is political culture. The political culture and democracy education conducted by involving the Kiayi, and directed at women voters and beginnervoter, because the majority of voters are women and the beginner-voter are in the moslem borading school (called: pasantren), that manage by the Kiayi.
\end{abstract}

Keywords - Absentia voter, the election of regional head, political awareness, political and democracy education.

\section{INTRODUCTION}

Since the fall of the New Order, the implementation of regional head election conducted directly. Before 2005, the regional head and deputy head of the region selected by the Local House of Representatives (DPRD). However, since the enactment of Law No. 32 of 2004 on Regional Government, The regional leaders were chosen directly by the people through Election, called Pilkada. In the district of Situbondo, first election held on 2010 and the second was held in 2015, which is also held in 19 other districts and cities in East Java.

Election is held directly in the hope that people can choose and determine directly the leader for the next 5 years, but in the 2015 elections of Situbondo number of absences (Absentia Voter) is still a problem. Based on studies showed that the absence of voters reached $25 \%$, and shows that the public has little or no political participation in to use their right to vote freely in the local elections. Though the election agenda, both at the national level (election) as well as at the level of local (election) is a form of the provision of facilities for citizens to participate in the use of their voting rights. When the voting right is ignored, then this will hurt democracy, that formulated as the government come from, by and for the people.

Absentia voter (voters who did not attend) could be interpreted as a group of people who had the vote, but did not vote in the elections. But in addition to the classification, absentia voters (voters who did not attend) also includes a number of voters that do not due to negligence of the administration by organizing institutions (KPU). Many factors that cause voters are more likely to abstain from voting. His apathetic is not just a form of mistrust of politicians right now, but rather the lack of political awareness of the people, plus their dominance of local political culture and the weakness of the electoral system itself.

\section{RESEARCH METHOD}

By using descriptive qualitative method, the simultaneous elections can be analyzed. The high absentee voter was more due to political factors, lack of political awareness because the majority of education level is still low, and there are patrialism in political culture is. The aims of this study, to find and describe all the affecting factors of the decrease in political participation, and the implementation of the election which is represented in absentia voters (voters who did not attend), and to know why absentia voter will be the best choice. Simultaneously this study provide political education for the public at large, about the importance of political participation, especially participation in the elections through the use of their voting rights. On the basis of these reasons, researchers took the theme "Absentia voter in the election of regional head in Situbondo Regency year 2015" Research on the absentia voter (voters who did not attend) in the elections of regional head of Situbondo in 2015, is qualitative research, which is in the process of data requires data that already exists in the form of text, images or opinions

\section{RESULT FINDINGS AND DISCUSSION}

Absentia voter (voters who did not attend) is a deviant movement, and could weaken the legitimacy of the elected government power. But, absentia voters (voters who did not attend) is not only as a political gesture, but also considered as 
activities of a person who did not vote at the time of elections, either because of intentional problems or due to technical problems. Absentia voter (voters who did not attend) is defined as someone who did not come and did not choose at the time of the election, because it is motivated by a variety of factors.

In the theory of political participation, [1] said that, the activities do not vote in elections classified into nonconventional political participation. It is also revealed by Milbrath M.L. Goel which identifies seven individual forms of political participation, which is inserted into the form of participation Aphatetic Inactives, which is not active participatory, never vote in elections. In many countries, with different terms and perspectives used, absentia voters (voters who did not attend) become a punishment for the political elite, because they are incapable of creating a state that aspired, as stipulated in the Constitution 1945.

In Indonesia, the absentia voters (voters who did not attend) takes place in each of the electoral operations and occur within a range of three orders, the old order. The presence of absentia voter (voter who did not attend) in every election, not solely political reasons, but also due to technical factors [2].

Absentia voter (voters who did not attend) can be defined as the steps taken by the person / groups, who has the right to vote, but do not vote in the general elections, either intentional or unintentional reason. Unintentional reason could be due to many factors, such as technical factors are traveling, working, sick, political or technical factors such as the problems of citizens who already have the right to vote but not recorded by the administration as a voter. The phenomenon of absentia voters (voters who did not attend) is a political maneuver of the unsatisfactory people on the performance of public officials (by election) that far from political reality. To the new era, if there are absentia voters (voters who did not attend), then it is considered as a moral movement to against the government. In reform era, that the vote is a right, so that absentia voters (voters who did not attend) is not only dominated by moral movement politically conscious not to use the right to vote, but also due to other factors.

According to Asfar, absentia concept is distinguished by the behavior of non-voting used to refer to the following phenomena; those who do not attend the polling station to protest; a person who attended the polling place but did not use their voting rights properly, and; people who use their voting rights, but with the way piercing the white part of the election card. While non-voting behavior aimed not to motivated to vote. However, both terms refer to the same result of the act: the voting rights are not used correctly.

In complexity absentia voters, can be classified: the groups of people who have voting rights constitutionally, but as a subject of the election was not listed definitively, voters who inadvertently made a mistake in voting, the people who really do not care about political affairs, or especially about elections, the people who consciously and against electoral and political party systems.
The trend of the phenomenon of absentee voters (voters who did not attend) in direct general election is basically not much different from the tendency of voting behavior that occurs in the elections at the national level, namely the critical and apathetic voters. A common characteristic of this model is distrust to the politicians [3]. According to Norris, "declining voter participation rate was associated with a decline in the level of satisfaction of the performance of government". Included in this analysis is a decrease in the level of trust the In addition, the disillusionment with the party or candidate is also reflected in the pragmatism of the public/voters. Apparently in the public/voters are still plenty of narrow views who expect their money or rewards from candidates as consideration for their ballots. If no one party or candidate that reward, people also do not want to exercise their voting rights.

It is clear that people become non-voters for political consciousness. Society may feel bored and apathetic to the party that is considered only benefit for the political elite themselves. The increasing cases of non-voters because of error that has spawned democratic imbalance in various fields. Activity leader election which too often makes people reluctant to participate when in reality their welfare is less assured [4].

Democracy is a form of government that all citizens have equal rights in decision-making that can change lives. Democracy allow citizens to participate either directly or through representatives in the formulation, development, and manufacture of the law. Democracy includes the social, economic, and cultural practices that allow their political freedom freely and equally. The word democracy comes from the two words "demos" meaning people dan "kratos" meaning government, or in other words the basic meaning of democracy is government of the people, or the more we know as a government of the people, by the people and for the people.

Democracy exists if the decision-makers collectively the most powerful in a system chosen through a general election that is fair, honest, and periodic and in the system of the candidates freely compete for votes and almost the entire adult population can be given voting rights. Democracy is a form or mechanism of government system as an effort to realize the sovereignty of the people (citizens' power) over the country to be run by the government.

The pillars of democracy is the principle of trias politics, that divides the political power as executive, legislative and judicial; to be realized in three types of state institutions are independent of each other (independent) and are in a rank parallel to each other. The three types of state institutions is a government agency that has the authority to establish and implement the executive authority, the competent courts the authority of the judicial and legislative branches that have the authority to exercise power legeslatif. Under this system legeslatif decision made by the public or by a representative who shall cooperate and act according to the aspirations of the people it represents and who elected through the electoral process. 
General Election 2015 in Situbondo conducted in accordance with the article 5, which includes two stages, namely preparation and implementation stages. Stages of preparation, which is carried out is an activity program planning and budgeting, preparation of regulatory conduct of elections, the preparation and adoption of technical guidelines for each stage of the conduct of elections, socialization / education / technical guidance, the establishment of an ad hock organizing committee, registration of election monitoring and voter registration [5]. Stages organizing elections regent and vice-regent include determining the terms of the candidate, support individual candidates, registration candidate, campaigns, reports and audit campaign finance, procurement and distribution logistics election of regent and vice regent, polling and counting of votes at polling stations, recapitulation the results of the vote count, determination elected pair post decision of the Court, proposing ratification of the appointment of the selected candidates.

Total Population by Age Group in 2015, Situbondo had a population of 779330 people, consisting of 391523 men and 407816 women, for more details as follows: Tabel 1. From Table 1. above it appears that the majority of Situbondo peoples only about $10 \%$ of the population does not have the right to vote, the others already have the right to vote [6].

The Population Seen from The Level of Education level of education reflects how many people are already free of illiteracy, and the extent to which the population has a political consciousness. To determine the level of public education in detail can be seen in the table below.

TABLE 1. Total Population by Level of Education in Situbondo 2015

\begin{tabular}{|l|l|l|l|}
\hline Education Level & 2013 & 2014 & 2015 \\
\hline $\begin{array}{l}\text { Elementary } \\
\text { Ungratuduate }\end{array}$ & 39.712 & 45.080 & 48.191 \\
\hline Elementary Graduate & 260.326 & 262.423 & 261.438 \\
\hline Secondary Graduate & 89.416 & 90.701 & 91.160 \\
\hline High School Graduate & 96.251 & 98.127 & 98.932 \\
\hline Diploma Programme & 5.071 & 5.267 & 5.378 \\
\hline S1 Graduate & 17.963 & 18.747 & 19.593 \\
\hline S2 Graduate & 809 & 829 & 898 \\
\hline S3 Graduate & 41 & 49 & 53 \\
\hline
\end{tabular}

Source: Dispenduk Kab. Situbondo 2015

The existence of the number of voters registered is vital data to the political process, due to the availability of accurate data of registered voters, then each candidate for Regent / Vice Regent will adopt a strategy to get the vote as much to be able to elect. Political Education to run the 2015 election properly, it needs political education by the Election Commission together with the organizing team at the level of districts [7]. The targets of political education is directed to women, the first voters through schools, the disabilities persons, stakeholders, the general public, and through cultural performances. For more details as in the table below.
Socialization the election of regional head not only face to face approach, but also through print and electronic media, to reach of the wider society in spaceless and timeless. The campaign is an delivery event of the vision and mission of the regent / deputy regent candidate, to the entire community in order to gain support by getting many votes.

The Election, general Election of 2015 is the second direct election and implemented simultaneously throughout Indonesia. Factors that influence the absentia voters . Factor that influence the absentia voters are: Low Levels of Education, The level of confidence in the government is declining, Political Culture, Unable to attend (out of town),

\section{CONCLUSION}

The Factors influencing absentia voters in Elections of Regional Head 2015 are: Low level of education which correlates to the low political awareness; The trust level to the government is decreased that indicated the communities desire to choose a new figure in the election of the regent / deputy regent new in 2015. The emersion of a new figure who has the support of the Kiayi in situbondo and the general public. As well as government officials who prefer to choose another candidate than incumbent candidate. There is political culture of patron client, from the Kiayi to the public on its common, this is a new finding, that the political culture has contributed significantly to the absence of voters (absentia voters) in the 2015 election in Situbondo, and The apatethic behavior in political awareness, by choosing to go out of town than at present in the elections.

In order for this study can contribute to society's political participation in the election, the researchers suggest the following: Political Education implemented with the involvement of Kyai, and directed at women voters and the first voters, because the majority of voters are women and the first voters are in Pondok Pesantren, In anticipation of a high rate of absentia voters (voters who did not attend), The Election Commission and the candidate leader must improve the socialization by giving the political education about the importance of democracy to the nation and the state; so that voters are aware and willing to be ellection participants.

\section{REFERENCES}

[1] Mas'oed, Mochtar dan McAndrews, Colin, "Perbandingan Sistem Politik", Gadjah Mada University Press, Yogyakarta 1995

[2] Ali, Novel, "Peradaban Komunikasi Politik (Potret Manusia Indonesia)", Phil. Rosda, Bandung, 1999.

[3] Arikunto, Suharsimi, "Prosedur Penelitian (Suatu Pendekatan Praktek)", Rineke Cipta, Jakarta, 1993.

[4] Faturohman, Deden dan Sobri, Wawan, "Pengantar Ilmu Politik", UMM Press, Malang, 2002.

[5] Firmanzah Ph.D, "Marketing Politik Antara Pemahaman dan Realitas," Yayasan Obor Indonesia, Jakarta, 2006.

[6] Purwoko, Bambang, "Demokrasi Mencari Bentuk", Program S2 Politik Lokal dan Otonomi Daerah Universitas Gadjah Mada, Yogyakarta., 2006.

[7] Wahid, KH Abdurrahman, HD, Halim, et.al, "Mengapa Kami Memilih Golput”, SAGON, 2009. 